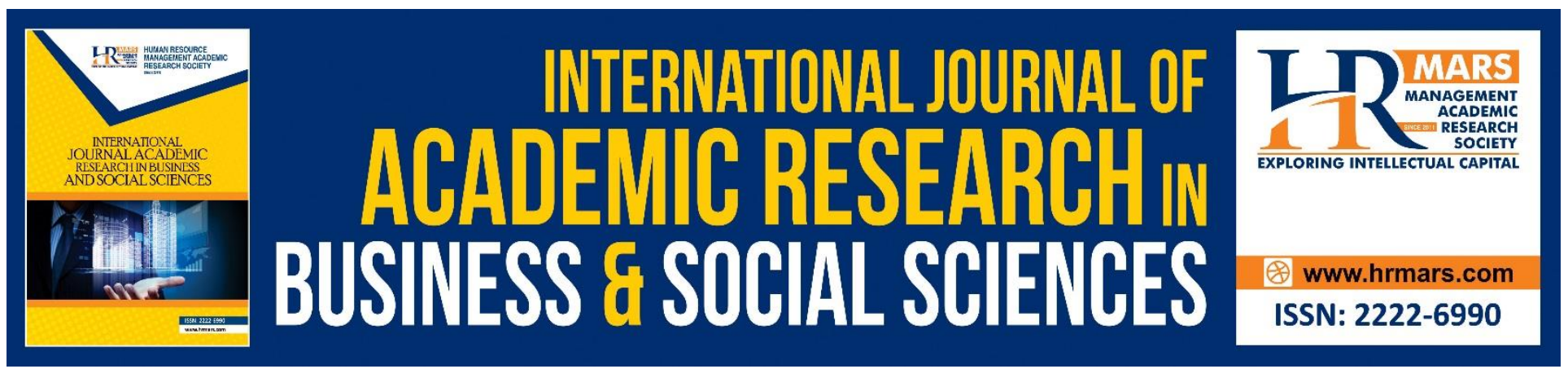

\title{
Strategic Planning Process and Organizational Performance in Nigerian Public Sector: A Review of Literature
}

Amar Aminu Umar, Norhilmi Muhammad, Isyaku Hassan

To Link this Article: http://dx.doi.org/10.6007/IJARBSS/v10-i7/7424

DOI:10.6007/IJARBSS/v10-i7/7424

Received: 08 April 2020, Revised: 16 May 2020, Accepted: 10 June 2020

Published Online: 29 July 2020

In-Text Citation: (Umar et al., 2020)

To Cite this Article: Umar, A. A., Muhammad, N., \& Hassan, I. (2020). Strategic Planning Process and Organizational Performance in Nigerian Public Sector: A Review of Literature. International Journal of Academic Research in Business and Social Sciences, 10(7), 367-382.

Copyright: (C) 2020 The Author(s)

Published by Human Resource Management Academic Research Society (www.hrmars.com)

This article is published under the Creative Commons Attribution (CC BY 4.0) license. Anyone may reproduce, distribute, translate and create derivative works of this article (for both commercial and non-commercial purposes), subject to full attribution to the original publication and authors. The full terms of this license may be seen at: http://creativecommons.org/licences/by/4.0/legalcode

Vol. 10, No. 7, 2020, Pg. 367 - 382

http://hrmars.com/index.php/pages/detail/IJARBSS

JOURNAL HOMEPAGE

Full Terms \& Conditions of access and use can be found at http://hrmars.com/index.php/pages/detail/publication-ethics 


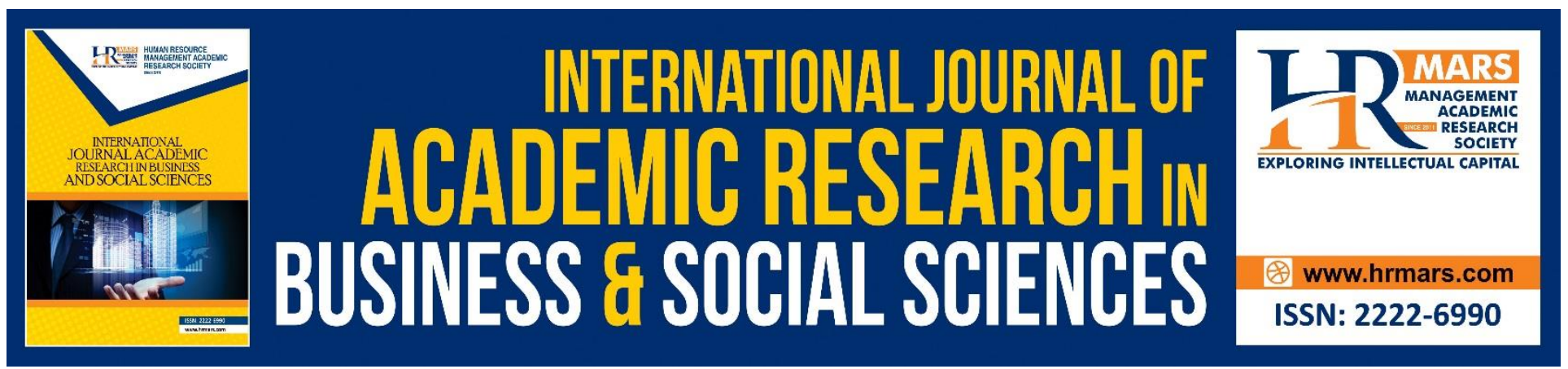

\title{
Strategic Planning Process and Organizational Performance in Nigerian Public Sector: A Review of Literature
}

\author{
Amar Aminu Umar ${ }^{1}$, Norhilmi Muhammad ${ }^{1}$, Isyaku Hassan² \\ ${ }^{1}$ Faculty of Business and Management, Universiti Sultan Zainal Abidin, Gong Badak, 21300 Kuala \\ Nerus, Terengganu, Malaysia, ${ }^{2}$ Faculty of Languages and Communication, Universiti Sultan Zainal \\ Abidin, Gong Badak, 21300 Kuala Nerus, Terengganu, Malaysia, Correspondence: Amar Aminu \\ Umar, Faculty of Business and Management, Universiti Sultan Zainal Abidin, 21300 Kuala Nerus, \\ Terengganu, Malaysia, \\ Email:amar_aminu@hotmail.com
}

\begin{abstract}
This paper aims to review the impact of strategic planning process on organizational performance in the Nigerian public sector. Strategic planning is reported to enhance organizational performance, operations, and overall effectiveness when used in the private and public sectors for decades. Several research findings indicate that large organizations regularly engage in strategic planning, and the plans developed and implemented had a positive impact on the organization's overall performance and effectiveness. Several findings indicated that strategic planning increases the organization's financial performance and longevity, and hence argued that public organizations should adopt the process of strategic planning. It is, therefore, prudent to determine the overall effectiveness of strategic planning for an organization. Hence, this paper focuses on the review of theory, practice, and the impact of strategic planning process on organizational performance among public sector organizations in Nigeria.
\end{abstract}

Keywords: Organizational Performance, Public Sector, Strategic Planning, Nigeria

\section{Introduction}

Strategic Planning (SP) is an imperative art that deals with formulating strategies and implementing them by several organizations for decades. It is a process that deals with developing certain strategies that will contribute to achieving the direction of an organization. Although it is a useful field of interest for many practitioners and researchers (Abubakar \& Hassan, 2017; Arend, Zhao, Song, \& Im, 2017; Poister, 2010; Spee \& Jarzabkowski, 2011) yet, there is still some debate regarding its usefulness and claims on its importance to particular environments (Arend et al., 2017). This criticism relates to the perception that SP is rigid and inflexible and that it is separate from processes, methods, and mechanisms of implementation (Bryson, Crosby, \& Stone, 2015). However, some scholars 
INTERNATIONAL JOURNAL OF ACADEMIC RESEARCH IN BUSINESS AND SOCIAL SCIENCES Vol. 10, No. 7, July, 2020, E-ISSN: 2222-6990 @ 2020 HRMARS

portray SP as a flexible tool whose adoption and application always take account of the organization's context, hence SP is argued to be beneficial. Flexibility can be achieved by adapting the characteristics of the strategic planning process (SPP) to the context of each organization.

Some of the features of the SPP include process comprehensiveness, stakeholder participation, formality and flexibility, use of strategy tools, and Role and Structure of planning functions (Jimenez, 2013; Poister, 2010). Although it is a useful field of interest for many practitioners and researchers (Arend, Zhao, Song, \& Im, 2017; Poister, 2010; Spee \& Jarzabkowski, 2011) yet, there is still some debate regarding its usefulness and claims on its importance to particular environments (Arend et al., 2017). Generally, strategic planning literature indicates that plans must be designed according to the needs of individual organizations, the literature on SP in the public sector suggests that adaptations to the private sector planning model are necessary if strategic planning is to be effective. Therefore, it is undoubtedly important for organizations to develop suitable strategies that will guide the direction and the future of their organizations to increase the chances of achieving their objective. According to literature findings, there are limited research works on the nature and extent of the usage of SP in the public sector of developing countries since major research on SP is mostly carried out in developed countries of the western world (Elbanna, Child, \& Dayan, 2013; Šuklev \& Debarliev, 2012). In the case of Nigeria, the country on which this research focuses on, very limited research is documented on this subject matter. The major literature data the researcher could access are mainly published documents before 2011, thus presenting an opportunity to update the literature with more recent empirical findings. Hence, this research will review and addresses the effect of strategic planning process on organization performance in Nigeria by looking specifically at the strategic planning processes used by the public organization at numerous government ministries and parastatal.

\section{Literature Review}

The literature review focuses on the theory and practice of strategic planning, particularly as it pertains to public sector organizations. For decades many research findings describe the benefit of strategic planning, and strategic management for profit-making organizations. Harvard University developed an SP model in the 1920s for their organization to use to find a "best fit" between the business mission and its environment. The military engaged in SP since the era of ancient conquerors and Roman generals, with more modern military strategies emerging with the American Civil War during the 1860s. Many adaptations have occurred since the wars of conquest, and when Harvard developed its first model, claiming that organizations need to undergo strategic planning exercises to remain competitive due to constant environmental changes. Although the private and public sectors have distinct differences, especially in the view of generating profit, both sectors share a strong motive which is aiming to attain a high level of achievement and deliver their mission successfully.

Many scholars agree that a strategic plan needs to be simple, promising, and neither too ambitious nor too demanding (Arend et al., 2017; Elbanna et al., 2013; Jimenez, 2013; Šuklev \& Debarliev, 2012; Tapinos et al., 2005). It should be planned in such a way that it is flexible to accommodate unexpected changes and other unforeseen factors that can negatively influence SP effectiveness. In today's world, most management teams or managers of an organization, profit, and non-profit organizations spend considerable time, energy, and money for formulating and assigning basic strategies of their organizations. However, the biggest problem is the implementation of the strategies that can 
INTERNATIONAL JOURNAL OF ACADEMIC RESEARCH IN BUSINESS AND SOCIAL SCIENCES

Vol. 10, No. 7, July, 2020, E-ISSN: 2222-6990 @ 2020 HRMARS

elaborate on the company's vision but the employees have a different perception of that, this may have a negative effect on achieving the company's objective that is derived from the vision. This means that the management must be prepared to ensure that all the employees in the organization understand the importance of a strategic plan.

\section{Strategic Planning in the Public Sector}

SP is being used by key government decision-makers precisely because of the drastic changes in the public sector which compel them to think strategically about government needs (Bryson et al., 2015). SP for the public sector deals with the function of the community, rather than the organization. (Bryson et al., 2015) indicate, strategic planning is important and probably will become a standard part of the repertoire of public planners. Nevertheless, strategic planning approaches developed in the private sector must be applied with care and caution to public purposes. According to most of the literature on public-sector strategic planning, it appears as though most researchers accept the definition of strategic planning as set out by (Streib \& Poister, 1990) "strategic planning is a disciplined effort to produce fundamental decisions shaping the nature and direction of government activities within constitutional bounds.

An interesting difference to note between corporate strategic planning and public-sector strategic planning is the point of focus. The focus in corporate planning is on the organization and improving its performance, while the focus of public sector planning is on the community and the agency's function, and the performance of the agency (Bryson et al., 2015). The strategic planner should also be mindful of the technical situations, as well as the political concerns that need to be addressed. To conclude, (Bryson et al., 2015) suggest that "when applied appropriately to the public-sector conditions, strategic planning provides a set of concepts, procedures, and tools for doing just that. We suspect the most effective public planners are now - and will be increasingly in the future- the ones who are best at strategic planning" (p. 20). Another situation to monitor is the distortion by the legislation governing the agency or program guidelines, or by the location of the planning agency with the agency affected (Bryson et al., 2015).

\section{Strategic Planning in the Private Sector}

According to (Mintzberg, 1994), the concept of strategic planning in the private sector took hold in corporate America and Communist Europe in the 1950s and 1960s, having been deeply entrenched in American business by the late 1960s and early 1970s. He also emphasizes that strategic planning dates further back in Chinese history, but was most evident in the 1949 translation of Henry Fayal's work (Ramakrishna, 2019). (Mintzberg, 1994) summarizes that most of the terms go together according to the literature, and "strategy formation s a planning process, designed or supported by planners, to plan to produce plans" (p. 32). "Thus, to quote Steiner (Steiner, 2010), who in turn quoted J.O. Schwarz (Schwarz, 2009) ... a plan... is tangible evidence of the thinking of management... it results from planning" (Steiner, 2010).

According to the literature, four components are tied together in the private sector strategic planning process: objectives, budgets, strategies, and programs. "In particular, the system offers a whole series of components, the relationships among which have never been made clear in practice" (Mintzberg, 1994). Therefore, it appears that strategic planning in the private sector assumes many forms: conventional strategic planning, strategic planning as a numbers game, and capital budgeting as ad hoc control to accommodate each organization, which becomes a portfolio of planning techniques. 
INTERNATIONAL JOURNAL OF ACADEMIC RESEARCH IN BUSINESS AND SOCIAL SCIENCES Vol. 10, No. 7, July, 2020, E-ISSN: 2222-6990 @ 2020 HRMARS

Furthermore, throughout (Mintzberg, 1994) critique of strategic planning, the discussion leads to what type of planning is needed. It is believed that organizations differ in their needs, so most will require a combination of planning and each unit will have to develop an individual strategic plan that best fits them, instead of "one plan fits all." Table 1 shows the Strategic Planning Models.

Table 1: Strategic Planning Models

\begin{tabular}{|l|l|l|}
\hline S/No. & Policy Models & Sub-Criteria \\
\hline 1. & Harvard Policy Model & - \\
\hline 2. & Strategic Planning Systems & - \\
\hline 3. & Stakeholder Management & - \\
\hline 4. & Strategic Issues Management & - \\
\hline 5. & Content Approaches & $\bigcirc$ Portfolio Methods \\
& & $\circ$ Competitive Analysis \\
\hline 6. & Process Strategies & $\bigcirc$ Strategic Negotiations \\
& & 0 Logical Incrementalism \\
& & 0 Framework for \\
& & Innovation \\
\hline
\end{tabular}

\section{The Strategic Planning Process}

Much of the literature on strategic planning focuses on the idea of a system or a process for planning. Authors commonly identify the steps involved in the planning process and treat planning as a very deliberate process that culminates in an explicit plan. (Bryson et al., 2015) provides a simple structure for the strategic planning process by defining the $A B C$ 's of strategic planning. According to Bryson, $A$ is where you are, $B$ is where you want to be and $C$ is how you get there. The vision, mission, and goals of the organization help it to move from $A$ to $B$. Strategy formulation connects between $A$ and $C$ while strategy implementation connects between B and C. Bryson's more complex planning process is a 10 step "strategy change cycle" as shown in Figure 1. 


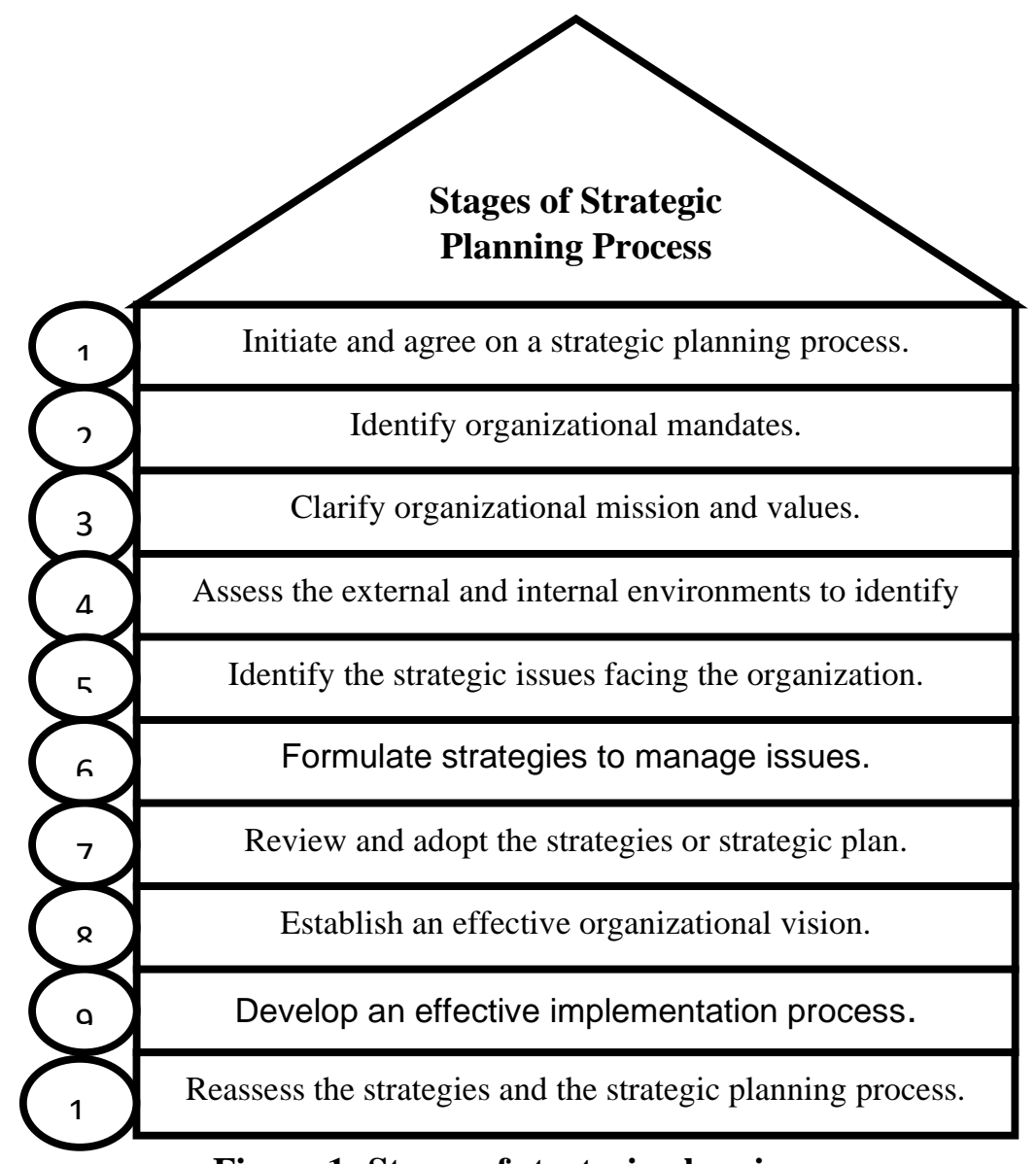

Figure 1: Stages of strategic planning process

SP has undergone a lot or general critıcısms trom researcners ana scnolars alike. (Wilkinson \& Monkhouse, 1994) insist that the public and private sectors are too different to operate under a single model of strategic planning. Private sector strategic planning assumes there is an executive in control of the entire organization who has the freedom to determine the present and future course of business. The assumption of strategic planning in the private sector assumes that the operating environment is competitive and that a profit motive exists and is the driving force in the planning requirement (Wilkinson \& Monkhouse, 1994). The authors say that in the public sector executive control often has its powers constrained by statute and regulation, which may predetermine the purpose of the organization and the level of freedom that exists to diversify and reduce; that the primary driver is not profit, but the maximization of output within the given budget system; and that certain elements of competition simply do not exist.

Wilkinson and Monkhouse observe that public sector organizations have been turning to the concept of strategic planning, but traditional models do not "fit" most public entities (Wilkinson \& Monkhouse, 1994). Bryson argues that a public sector organization-- and most other organizations may not need every element in the strategic planning models developed (Bryson et al., 2015). This means picking and choosing the elements that are important and" fit" the particular organization. As with any new management tool, there will be researchers poised on both sides of the issue as to whether the technique works. Every organization is going to have a different experience with the strategic planning process, and there can be a breakdown at any point in the system, which may be 
INTERNATIONAL JOURNAL OF ACADEMIC RESEARCH IN BUSINESS AND SOCIAL SCIENCES Vol. 10, No. 7, July, 2020, E-ISSN: 2222-6990 @ 2020 HRMARS

why it is subsequently deemed a failure. As Berry and Wechsler (1995) illustrate, the history of public administration provides many examples of new management tools that have been hailed for their promise to improve government performance, Planning- Programming-Budgeting-System (PPBS), Management by Objectives (MBO), and Quality Circles, which were all met with enthusiasm from people looking for answers to solve certain problems (Berry \& Wechsler, 1995).

If negative results are reported with the latest technique, then some are very quick to deem it a failure. In regards to strategic planning, its most ardent critic has been Henry Mintzberg. In 1994, Mintzberg presented extensive evidence that strategic planning had not been effective in the private sector and used examples from President Johnson's administration (the 1960s) as an example of failure in the public sector. Mintzberg has become a critic of traditional planning models, where he concludes that strategic planning has failed in helping organizational leaders develop vision, mission, and strategy (Berry \& Wechsler, 1995). Berry and Wechsler (1995) point to their research, in which they claim "strategic planning is taken as a management tool, almost all state agencies report being motivated by their desire to set program and policy direction, to emulate exemplary practice drawn from the private sector, and to respond to budgetary and fiscal pressures" (p. 168). As suggested in the literature, strategic planning seems to have offered public sector organizations a mechanism for achieving proactive, purposeful action for the agency's future agenda.

\section{Public Organization and the Planning Process}

Another common theme in strategic planning literature deals with the role of people in the planning process. Generally, the literature acknowledges that people are an important part of the process and critical to successfully implementing strategic management (Bloom \& Menefee, 1994; Kemp Jr, Funk, \& Eadie, 1993; Poister \& Streib, 2005; Vinzant \& Vinzant, 1999). Streib (1992) acknowledges that it is difficult to define the components of a successful strategic effort, but he identifies four management functions that he deems critical to the success of any strategic planning effort: leadership, human resources, managerial skills, and external support (Poister \& Streib, 2005). The importance of people in the strategic planning process is evident in the fact that three of the four critical functions specifically address people and their role in planning. Eadie (1993) states the importance of people to the planning process by writing, "And the human factor looms large in strategy implementation, as well as in formulation and selection of strategies". Hosmer (1994) describes strategic management as an organizational task. The author writes, "Strategic management is an organizational task and requires an integrated effort by all members of the organization for successful completion".

Bloom (1994) states that the "failure to involve interested parties in the planning process can reduce the chances for implementation" (p. 254). He goes on to acknowledge the relationship between ownership of the plan and accountability and suggests that involvement in the planning process leads to greater accountability for the results of decisions. Kukalis (1991) look at the specific role of the corporate planner and suggest that planning must be done by line managers because it is likely to fail if it is not a people-interactive process. The authors acknowledge the existence of and need for corporate planners but view the corporate planner as an organizer who facilitates the process of planning (Kukalis, 1991). Bryson (2015) acknowledges a similar role that they refer to as a process champion. In their study of strategic planning in government, they identify that a strong process champion was present everywhere that strategic planning was implemented (Bryson et al., 2015). In her study of planning at the University of Wisconsin-Madison, Paris (2004) shows the use of "point people" assigned to specific priorities identified in the plan. This point people can communicate 
INTERNATIONAL JOURNAL OF ACADEMIC RESEARCH IN BUSINESS AND SOCIAL SCIENCES Vol. 10, No. 7, July, 2020, E-ISSN: 2222-6990 @ 2020 HRMARS

across the university and break down the silos to get people focused on the institution's common goal (Paris, 2004).

\section{Application of Strategic Planning in Public Organizations}

While strategic planning has become popular in the public sector, there is debate on whether strategic planning in its private sector form can be applied to public organizations. Bloom (1994) depicts this divide as he writes, "Although no one appears to rule out the applicability of strategic planning, some suggest that the differences between the public and private sectors are significant enough that any strategic approach to public sector planning requires extensive adaptation" (Bloom $\&$ Menefee, 1994). Some of these differences include the political environment of the public sector, the involvement of external constituents, the difficulty of implementing plans, and the lack of organizational autonomy (Bloom, 1994). Bryson (2015) identifies that "the more numerous stakeholders, the conflicting criteria they often use to judge governmental performance, the pressures for public accountability, and the idea that the public sector is meant to do what the private sector cannot or will not do, all militate against holding government strategic planning practice to private-sector standards" (p. 1002). Kukalis (1991) echoes this question of applicability by identifying that "successful application is a matter of careful tailoring to the unique circumstances of a particular public organization" (p. 447). He goes on to write, "A boilerplate approach, in short, is likely to prove inadequate, if not fatal, and the organization that knows itself well and adapts its planning approaches accordingly is far more likely to experience success in planning.

Vinzant and Vinzant (1996) address the issue of organizational autonomy and its effects on the planning process of private and public organizations. Organizational autonomy is generally considered an important condition in strategic management implementation because organizations having significant autonomy can implement successful change when necessary. Private and public organizations typically differ in their level of organizational autonomy which affects the planning process. Since public organizations tend to be restricted in their autonomy by statutory and fiscal constraints, these organizations face unique challenges when engaging in strategic planning. Wilkinson and Monkhouse (1994) support this position as they acknowledge that it is not uncommon for executives in public sector organizations to have their powers constrained by statute and regulation. Intercollegiate athletic departments, which operate within higher education institutions, face additional constraints particular to higher education. Higher education institutions typically incorporate a principle of shared governance which limits organizational autonomy of colleges and universities even more significantly than governmental and other public organizations. The restricted autonomy and the involvement of more individuals in processes and decisions make strategic planning challenging in the higher education setting.

Streib (1992), after identifying the importance of leadership to the strategic planning process, questions whether the public sector possesses the level of leadership necessary to succeed. Streib attributes this, at least partially, to the difficulty in maintaining a shared vision among elected and appointed officials who change frequently due to elections and staff changes. Streib and Poister (1990) discuss public sector limitation in terms of strategic capacity and question whether public organizations can compile the information necessary for the completion of a strategic plan. While continuity of leadership certainly can help an organization maintain a consistent vision which would, in turn, help the strategic planning process, one could argue that the authors' questioning of leadership and strategic capacity within public organizations is too general and fails to acknowledge 
INTERNATIONAL JOURNAL OF ACADEMIC RESEARCH IN BUSINESS AND SOCIAL SCIENCES

Vol. 10, No. 7, July, 2020, E-ISSN: 2222-6990 @ 2020 HRMARS

individual levels of leadership and strategic capacity. It is safe to assume that just as there are strong and weak leaders in the private sector, there are also strong and weak leaders of public organizations.

\section{The Effectiveness of Strategic Planning in Nigerian Government Ministries}

Measuring the effectiveness of strategic planning as a management practice in government ministries and parastatals is a difficult task. The dynamic nature of the government organization environment makes it nearly impossible to attribute gains in efficiency or effectiveness exclusively to the strategic planning effort. Dooris et al. (2004) stated that the writing: strategic planning in a government organization occurs in a complex, dynamic, real-world environment, not readily amenable to controlled studies, or even to quasi-experimental designs (Dooris, 2004). It is difficult to parse out the measurable effects of strategic planning from the influences of such other important factors as institutional leadership, demographic change, fluctuations in state and federal funding, politics, the actions of competing organizations, social and cultural forces, and the like. Thus, to the best of our knowledge, the present empirical evidence about whether strategic planning does or does not work in higher education is less than conclusive. (p. 9) Dooris et al. (2004).

This formidable challenge is the main reason that no studies measuring the effect of strategic planning in government organizations could be found. Birnbaum (2002) found very little evidence of attempts to measure the effectiveness of any of the management fads he researched. He writes, "There are few published examples in the academic sector of attempts to assess the institutional consequences of a management fad through data that provide evidence either of organizational outcomes or the satisfaction of users" (p. 10) (Birnbaum, 2012). Birnbaum attributes this lack of quantifiable analysis, at least partially, to the differences in the public and private sectors. Businesses in the private sector, Birnbaum notes, are data-driven and accustomed to measuring effectiveness through quantitative data and statements of profit and loss. Government organizations, on the other hand, are more loosely coupled and quantitative measures have not valued the way they are in the private sector. This means that data moves more slowly in government ministries or parastatal where narratives and "counter-narratives" play a more important role Given the lack of empirical evidence that exists to support a claim of effectiveness, conclusions about strategic planning's effectiveness in government organizations can only be based on observations of its use by institutions. Dooris (2004) notes that by the late 1990s, strategic planning had "in many respects become mainstreamed in government organizations" (p. 28). Further, he added, strategic planning's inclusion in the expectations of accrediting organizations is an indication that strategic planning is considered effective.

\section{Importance of Strategic Planning in Nigerian Public Organization}

Yow et al. (2000) encourage the use of planning and clearly state its importance by offering this recommendation, "Planning not only should be done, but must be done, for an organization to achieve optimum success" (Yow, Migliore, Loudon, Bowden, \& Stevens, 2000). Moreover, organizations face many challenges in their effort to enhance performance. These challenges come from both external and internal forces. SP is useful in addressing these challenges and in improving organizational performance. The importance of SP in the management of organizations has been documented by several authors Example (Grant, 2003) and is evident in its wide adoption for use in all types of organizations regardless of sector or size (Arend et al., 2017; Ghobadian, O'regan, Thomas, \& Liu, 2008; Green Jr \& Medlin, 2003; Griggs, 2002; Wandjiva, 2011). SP is concerned with establishing 
INTERNATIONAL JOURNAL OF ACADEMIC RESEARCH IN BUSINESS AND SOCIAL SCIENCES Vol. 10, No. 7, July, 2020, E-ISSN: 2222-6990 @ 2020 HRMARS

the long term direction of the whole organization by deliberatively developing an understanding of the environment and devising visions, missions, objectives, and strategies (Schwenk \& Shrader, 1993). It is a useful tool for:

1. Providing both long term direction and guidance for medium-term decisions.

2. Enhancing coordination and communication.

3. Setting priorities and focusing on resource allocation in key areas.

4. Enhancing the appreciation of organizational goals among stakeholders resulting in them taking ownership of the organization's programs and

5. Enhancing staff morale and commitment

Furthermore, SP is also useful in creating contexts for decision making in that it demands the development of a thorough understanding of the environment within which the organization operates as a precondition to the development of strategies. SP ultimately enhances organizational performance (Murphy, 2011; Rajagopalan, Rasheed, \& Datta, 1993). However, the literature on the impact of SP on organizational performance lacks consensus (Song et al, 2015). For example, Priem, Rasheed, and Kotulic (1995) found that SP has a positive effect on firm performance, for organizations operating in unstable and complex environments, and no effect for those operating in stable environments (Priem, Rasheed, \& Kotulic, 1995). Furthermore, numerous authors found that SP positively affects performance (Al-Shammari \& Hussein, 2007; Brews \& Hunt, 1999; Miller \& Cardinal, 1994). (Ghobadian et al., 2008) found no systematic relationship. Studies that have consolidated the literature on the effect of SP on organizational performance have found a net positive effect (e.g. Miller and Cardinal, 1994; Schwenk and Shrader, 1993). Table 2 illustrates a summary of the characteristics of strategic planning process by various Authors.

Table 2: Characteristics of Strategic Planning Process

\begin{tabular}{|c|c|c|c|c|}
\hline $\mathrm{S} / \mathrm{No}$ & & Characteristics & $\begin{array}{c}\text { Author's } \\
\text { name }\end{array}$ & $\begin{array}{l}\text { Year of } \\
\text { publicati } \\
\text { on }\end{array}$ \\
\hline 1. & $\begin{array}{l}0 \\
0 \\
0 \\
0\end{array}$ & $\begin{array}{l}\text { Comprehensiveness } \\
\text { Flow and participation } \\
\text { Strategic planning process tools } \\
\text { Strategic plan duration }\end{array}$ & Murphy & 2011 \\
\hline 2. & $\begin{array}{l}0 \\
0 \\
0 \\
0\end{array}$ & $\begin{array}{l}\text { Structure and role of corporate } \\
\text { planning } \\
\text { Departments } \\
\text { Linkages between strategic } \\
\text { planning and other } \\
\text { decision-making systems } \\
\text { Participation } \\
\text { Role of strategic planning in overall } \\
\text { Management }\end{array}$ & Grant & 2003 \\
\hline
\end{tabular}


INTERNATIONAL JOURNAL OF ACADEMIC RESEARCH IN BUSINESS AND SOCIAL SCIENCES Vol. 10, No. 7, July, 2020, E-ISSN: 2222-6990 @ 2020 HRMARS

\begin{tabular}{|c|c|c|c|c|}
\hline 3. & $\begin{array}{l}0 \\
0 \\
0 \\
0\end{array}$ & $\begin{array}{l}\text { Process formality } \\
\text { Size of planning effort } \\
\text { Process sophistication } \\
\text { Top management team } \\
\text { involvement } \\
\text { Middle management team } \\
\text { involvement } \\
\text { Planning horizon }\end{array}$ & Haug & 1997 \\
\hline 4. & $\begin{array}{l}0 \\
0 \\
0 \\
0 \\
0\end{array}$ & $\begin{array}{l}\text { Planning implementation } \\
\text { Market research competence } \\
\text { Key personnel involvement } \\
\text { Staff planning assistance } \\
\text { Innovativeness of strategies }\end{array}$ & $\begin{array}{l}\text { Veriyath } \\
\text { and Shortell }\end{array}$ & 1993 \\
\hline 5. & $\begin{array}{l}0 \\
0 \\
0 \\
0 \\
0 \\
0 \\
0\end{array}$ & $\begin{array}{l}\text { Comprehensiveness } \\
\text { Rationality } \\
\text { Degree of political activity } \\
\text { Participation/involvement } \\
\text { Plan duration } \\
\text { Extent /type of conflict } \\
\text { Planning implementation }\end{array}$ & $\begin{array}{l}\text { Rajagopala } \\
n \text { et al. }\end{array}$ & 1993 \\
\hline 6. & $\begin{array}{l}0 \\
0 \\
0 \\
0\end{array}$ & $\begin{array}{l}\text { Planning extensiveness } \\
\text { Role of corporate planning staff } \\
\text { Planning horizon } \\
\text { Frequency of plan review }\end{array}$ & Kukalis & 1991 \\
\hline \multirow[t]{2}{*}{7.} & $\begin{array}{l}0 \\
0\end{array}$ & $\begin{array}{l}\text { Use of information } \\
\text { Generation and evaluation of } \\
\text { alternatives } \\
\text { Conflict resolution } \\
\text { Integration }\end{array}$ & Eisenhardt & 1989 \\
\hline & 0 & Comprehensiveness & $\begin{array}{l}\text { Fredrickson } \\
\text { and } \\
\text { Mitchell }\end{array}$ & 1984 \\
\hline 8. & $\begin{array}{l}0 \\
0 \\
0 \\
0 \\
0 \\
0 \\
0 \\
0\end{array}$ & $\begin{array}{l}\text { The adaptive aspect } \\
\text { The integrative aspect } \\
\text { Formality } \\
\text { Internal complexity } \\
\text { External complexity } \\
\text { Specific MIS for planning } \\
\text { Accounting systems } \\
\text { Supplemental sources of } \\
\text { information }\end{array}$ & Ryne's & 1987 \\
\hline
\end{tabular}


INTERNATIONAL JOURNAL OF ACADEMIC RESEARCH IN BUSINESS AND SOCIAL SCIENCES Vol. 10, No. 7, July, 2020, E-ISSN: 2222-6990 @ 2020 HRMARS

To encourage the use of planning by a public organization, the following suggestion has been made as SP is an important tool to be used by a public organization to develop more effective and efficient units.

1. A sense of enthusiasm in your athletics department.

2. A five-year plan in writing to which most everyone is committed.

3. A sense of commitment by the entire department to its overall direction.

4. Clear job duties and responsibilities.

5. Time for the leaders to do what they can most effectively do for the athletics program.

6. Clear and evident improvement in the effectiveness of each staff member.

7. The ability to measure very specifically the growth and contribution made by the leaders and other staff members at the close of their careers in the department.

8. Guaranteed leadership of the organization program because a plan is in place in writing and is understood. Even more important, a management team and philosophy will be in place to guide the department into its next era of growth.

\section{Conclusion}

This paper demonstrates that strategic planning is an important instrument for every organization, both private and public. Besides, strategic planning is influenced by several factors, such as strategic choice, strategic management, organizational structure, and down upward communication. These factors include firm-level factors and industry factors. The firm-level factors include resources, structure, organizational culture, chief executive officer attributes, and board characteristics. These factors exist within the organization and, in most cases, the organization has control over them. On the other hand, the strategy choice is influenced by the business environment in which the business operates, and organizations should be able to scan the environment critically to avoid other challenges that may arise. These factors are normally beyond the organization's control because they are external, and therefore difficult to manage. The strategy links the organization to the environment and the strategy chosen in turn affects the performance of an organization. The performance may vary from one strategy to another depending on the measure of performance used by the organization. The tools used in measuring the performance are critical when addressing the success factors for implementation.

This study advances our understanding of how various policy models, such as the Harvard policy model, stakeholder management, and strategic planning systems, are applied to increase the stakeholders' participation in the strategic planning process, particularly in the public sector. This, in turn, could lead to effective strategic planning and enhance organizational performance. Besides, this review of literature provides valuable information on the relationship between strategic planning process and organizational performance in the Nigerian public sector. This contribution could be beneficial to managers, stakeholders, and government establishments in ensuring inclusive effective decision-making. Although the Nigerian government has a long history of SP implementation, it is important for the organizations to carefully examine the contingent factors that determine the kind of strategy that is selected for implementation to achieve the organizations' objectives. 
INTERNATIONAL JOURNAL OF ACADEMIC RESEARCH IN BUSINESS AND SOCIAL SCIENCES

Vol. 10, No. 7, July, 2020, E-ISSN: 2222-6990 @ 2020 HRMARS

\section{References}

Abubakar, U. I., Hassan, I. (2017). Theoretical perspectives of management and their application in Abubakar Rimi Television, Kano State, Nigeria. IOSR Journal of Humanities and Social Science, 22 (11): 18-28. doi: 10.9790/0837-2211081828

Aldehyyat, J., Al Khattab, A., \& Anchsor, J. (2011), The use of strategic planning tools and techniques in hotels in Jordan. Management Research News, 34 (4), 43-60.doi: 10.1108/01409171111117898/full/html

Al-Shammari, H. A., \& Hussein, R. T. (2007). Strategic planning-firm performance linkage: Empirical investigation from an emergent market perspective. Journal of Competitiveness Studies, 15(1/2), 15-23.

Arend, R. J., Zhao, Y. L., Song, M., \& Im, S. (2017). Strategic planning as a complex and enabling managerial tool. Strategic Management Journal, 38(8), 1741-1752.doi: 10.1002/smj.2420

Berry, F. S., \& Wechsler, B. (1995). State agencies' experience with strategic planning: Findings from a national survey. Public administration review, 55(2), 159-168.doi: 10.2307/977181

Birnbaum, L. S. (2012). NIEHS's new strategic plan. Retrieved from: https://ehp.niehs.nih.gov/doi/full/10.1289/ehp.1205642

Bloom, M. J., \& Menefee, M. K. (1994). Scenario planning and contingency planning. Public Productivity \& Management Review, 17(3), 223-230.doi: 10.2307/3380654

Brews, P. J., \& Hunt, M. R. (1999). Learning to plan and planning to learn: Resolving the planning school/learning school debate. Strategic Management Journal, 20(10), 889-913.doi: 10.1002/(SICI)1097

Bryson, J. M., Crosby, B. C., \& Stone, M. M. (2015). Designing and implementing cross-sector collaborations: Needed and challenging. Public administration review, 75(5), 647-663.doi: 10.1111/puar.12432

Chandler, J. A. D. (1962). Strategy and Structure: Chapters in the History of the American Industrial Enterprise. Cambridge, MA: MIT Press.

Deal, E. T., \& Kennedy, A. A. (2000). Corporate Culture. Cambridge MA: Persons.

Debarliev, S., \& Suklev, B. (2012). Strategic planning effectiveness comparative analysis of the Macedonian context. Economic and Business Review, 14(1), 63-93.

Dooris, M. (2004). Joining up settings for health: a valuable investment for strategic partnerships?. Critical Public Health, 14(1), 49-61.doi: 10.1080/09581590310001647506

Devanna, M. A., Fombrun, C., \& Tichy, N. (1981). Human resource management: A strategic perspective. Organizational Dynamics, 9 (3): 51-68.doi: 10.1016/0090-2616(81)90038-3

Elbanna, S., Child, J., \& Dayan, M. (2013). A model of antecedents and consequences of intuition in strategic decision-making: Evidence from Egypt. Long Range Planning, 46(1-2), 149-176. doi: 10.1016/j.Irp.2012.09.007

Ghobadian, A., O'regan, N., Thomas, H., \& Liu, J. (2008). Formal strategic planning, operating environment, size, sector and performance: Evidence from the UK's manufacturing SMEs. Journal of General Management, 34(2), 1-20.doi: 10.1177/030630700803400201

Goleman, D. (1998). What makes a leader? Harvard Business Review, 1(1), 93-102.

Goleman, D. (2000). Leadership that gets results. Harvard Business Review, 78(2), 78-90.

Grant, R. M. (2003). Strategic planning in a turbulent environment: Evidence from the oil majors. Strategic Management Journal, 24(6), 491-517.doi: 10.1002/smj.314 
INTERNATIONAL JOURNAL OF ACADEMIC RESEARCH IN BUSINESS AND SOCIAL SCIENCES

Vol. 10, No. 7, July, 2020, E-ISSN: 2222-6990 @ 2020 HRMARS

Green, Jr, K. W., \& Medlin, B. (2003). The strategic planning process: The link between mission statement and organizational performance. Academy of Strategic Management Journal, 12(1), 2-23.

Gregerson, H. B., Morrison, A. J., \& Black, J. S. (1998). Developing leaders for the global frontier. Sloan Management Review, 40(1):21-32.

Griggs, H. E. (2002). Strategic planning system characteristics and organisational effectiveness in Australian small-scale firms. Irish Journal of Management, 23(1), 23-51.

Hosmer, L. T. (1994). Strategic planning as if ethics mattered. Strategic Management Journal, 15(S2), 17-34. Doi: $10.1002 / s m j .4250151003$

Huselid, M. A., \& Becker, B. E. (1997). The impact of high performance work system, implementation effectiveness, and alignment with strategy on shareholder's wealth. Academy of Management Proceedings, 1(1), 144-149.doi: 10.5465/ambpp.1997.4981101

Huselid, M., Jackson, S., \& Schuler, R. (1997). Technical and strategic human resource management effectiveness as determinants of firm performance. Academy of Management Journal, 40 (1), 171-188.doi: 10.5465/257025

Jimenez, B. S. (2013). Strategic planning and the fiscal performance of city governments during the Great Recession. The American Review of Public Administration, 43(5), 581-601.doi: 10.1177/0275074012451051

Kemp J, E. J., Funk, R. J., \& Eadie, D. C. (1993). Change in chewable bites: Applying strategic management at EEOC. Public Administration Review, 53(2), 129-134.doi: 10.2307/976705

Kotler P., Armstrong G., Saunders J., \& Wong, V. (2002). Principles of marketing (3rd ed). Harlow: Financial Times Prentice Hall.

Kukalis, S. (1991). Determinants of strategic planning systems in large organizations: A contingency approach. Journal of Management Studies,28(2), 143-160. doi: 10.1111/j.14676486.1991.tb00274.x

Leggate, P., \& Thompson, J. (1997). The management of development planning in international schools. International Journal of Educational Management, 11(6): 268- 273.doi: 10.1108/09513549710186894/full/html

Louw, L., \& Venter, P. (2006). Strategic Management: Winning in the Southern African workplace. Cape Town: Oxford University Press.

Sababu, B. (2007). Strategic management: The analytical approach. Nairobi: Jomo Kenyatta Foundation.

Miller, C. C., \& Cardinal, L. B. (1994). Strategic planning and firm performance: A synthesis of more than two decades of research. Academy of Management Journal, 37(6), 1649-1665.doi: $10.5465 / 256804$

Mintzberg, H. (1994). The fall and rise of strategic planning, Harvard Business Review, 72(1), 107-114.

Murphy, R. (2011). Strategic planning in Irish quantity surveying practices (Doctoral dissertation). Heriot-Watt University, United Kingdom.

Paris, K. A. (2004). Moving the strategic plan off the shelf and into action at the University of Wisconsin-Madison. New Directions for Institutional Research, 123 (1), 121-127. doi: 10.1002/ir.126

Poister, T. H. (2010). The future of strategic planning in the public sector: Linking strategic management and performance. Public Administration Review, 70 (1), 246-254.doi: 10.1111/j.1540-6210.2010.02284.x 
INTERNATIONAL JOURNAL OF ACADEMIC RESEARCH IN BUSINESS AND SOCIAL SCIENCES

Vol. 10, No. 7, July, 2020, E-ISSN: 2222-6990 @ 2020 HRMARS

Priem, R. L., Rasheed, A. M., \& Kotulic, A. G. (1995). Rationality in strategic decision processes, environmental dynamism and firm performance. Journal of Management, 21(5), 913-929.doi: 10.1177/014920639502100506

Rajagopalan, N., Rasheed, A. M., \& Datta, D. K. (1993). Strategic decision processes: Critical review and future directions. Journal of Management, 19(2), 349-384.doi: 10.1016/01492063(93)90057-T

Ramakrishna, N. (2019). Henry Fayol's principles of management and its applicability in contract staffing. International Journal of Management, IT and Engineering, 9(3), 168-182.

Schein, E. H. (2009). Organization Psychology. New Jersey: Prentice Hall.

Schuler, R. S. (1992). Strategic human resource management: Linking the people with the strategic needs of the business. Organizational Dynamics, 21 (1), 18-33.doi: 10.1016/00902616(92)90083-Y

Schuler, R. S., \& Jackson, S. E. (1987). Linking competitive strategies with human resource management practices. Academy of Management Executive, 1 (3): 207-219.doi: 10.5465/ame.1987.4275740

Schuler, R. S., \& Jackson, S. E. (1987). Organizational strategy and organizational level as determinants of human resources management practices. Human Resources Planning, 10 (3), 125-143.

Schuler, R. S., \& Walker, J. W. (1990). Human resources strategy: Focusing on issues and actions. Organizational Dynamics, 19 (1), 4-20.doi: 10.1016/0090-2616(90)90045-Q

Schwarz, J. O. (2009). Business wargaming: developing foresight within a strategic simulation. Technology Analysis \& Strategic Management, 21(3), 291-305.doi: 10.1080/09537320902750590

Schwenk, C. R., \& Shrader, C. B. (1993). Effects of formal strategic planning on financial performance in small firms: A meta-analysis. Entrepreneurship Theory and Practice, 17(3), 53-64.doi: $10.1177 / 104225879301700304$

Spee, A. P., \& Jarzabkowski, P. (2011). Strategic planning as communicative process. Organization Studies, 32(9), 1217-1245.doi: 10.1177/0170840611411387

Steiner, G. A. (2010). Strategic Planning. New York: Simon \& Schuster.

Streib, G., \& Poister, T. H. (1990). Strategic planning in US cities: Patterns of use, perceptions of effectiveness, and an assessment of strategic capacity. The American Review of Public Administration, 20(1), 29-44.doi: 10.1177/027507409002000103

Tapinos, E., Dyson, R., \& Meadows, M., (2005). The impact of performance measurement in strategic planning. International Journal of Productivity and Performance Management, 54 (5/6),370384.doi: 10.1108/17410400510604539/full/html

Ulrich, D. (2000). How the human resource function can create value and drive strategic success. Retrieved from: https://store.hbr.org/product/how-the-human-resource-function-cancreate-value-and-drive-strategic-success/B0003C

Ulrich, D. (1998). A new mandate for human resources. Retrieved from: https://hbr.org/1998/01/anew-mandate-for-human-resources

Vinzant, J. C., \& Vinzant, D. H. (1999). Strategic management spin-offs of the Deming approach. Journal of Management History, 5(8), 516-531.doi: 10.1108/13552529910290629/full/html. 
INTERNATIONAL JOURNAL OF ACADEMIC RESEARCH IN BUSINESS AND SOCIAL SCIENCES

Vol. 10, No. 7, July, 2020, E-ISSN: 2222-6990 @ 2020 HRMARS

Wandjiva, J. T. (2011). An exploratory study on strategic planning and the role of communication in the public service of Namibia with specific reference to the Ministry of Gender Equality and Child Welfare (Doctoral dissertation). Namibia University of Science and Technology, Namibia.

Wright P., Smart, D., \& McMahan, G. (1995). Matches between human resources and strategy among NCCA Basket Teams. Academy of Management Journal, 38 (4), 1052-1074.doi: $10.5465 / 256620$

Wright, P. M., \& McMahan, G. C. (1992). Theoretical perspectives for strategic human resource management. Journal of Management, 18 (2), 295-320.doi: 10.1177/014920639201800205

Wright, P. M. (1998). Introduction: Strategic human resource management research in the $21^{\text {st }}$ century. Human Resource Management Review, 8 (3), 187-152.doi: 10.1016/S10534822(98)90001-8

Wilkinson, G., \& Monkhouse, E. (1994). Strategic planning in public sector organizations. Executive development. Executive Development, 7(6), 16-19.doi:

10.1108/09533239410071878/full/html

Yabs, J. (2010). Strategic Management Practices 2nd edition. Nairobi: Lelax Global (K) Ltd

Youndt, M. A., \& Scott, S.A. (1996). Human resource management, manufacturing strategy, and firm performance. Academy of Management Journal, 39 (4), 836-857.doi: 10.5465/256714

Yow, D. A., Migliore, R. H., Loudon, D. L., Bowden, W. W., \& Stevens, R. E. (2000). Strategic Planning for Collegiate Athletics. New York: Psychology Press. 